\title{
Renovation of the block in Madrid in accordance with criteria of Isover MultiComfort House
}

\author{
Vladimir Elistratov ${ }^{1, *}$, Olga Pastukh $^{1}$, Svetlana Golovina ${ }^{1}$, and Nikolai Elistratov ${ }^{1}$ \\ ${ }^{1}$ Saint-Petersburg State University of Architecture and Civil Engineering, 2-ya Krasnoarmeiskaya St. \\ 4, Saint-Petersburg, 190005, Russia
}

\begin{abstract}
This study is dedicated to comprehensive approach to the problems connected with living in and operation of the old housing facilities stock of Madrid. The article provides a review to a developed area located in Colonia Ciudad Pegaso in Madrid. This area comprises two four-storeyed residential houses built in 1956, single-storeyed sheds and a small square. It has been found that as at 2017 the existing buildings do not meet the passive house criteria and the territory is not adapted to comfort living of people with limited mobility. Taking into account immediacy of this problem, the article offers the project for renovation of the area concerned. This project was developed within the regular urban program of Madrid called Mad-Re "Madrid Recupera" and the concept of sustainable development. During development of the project the requirements of Isover-Saint Gobain multi-comfort house were taken into account, barrierfree environment for comfortable living of different social groups was created, storage places were reorganized and the territory of the square was adapted to recreation of local citizens. As a result of the above works, there was created a new architectural appearance of the apartment block aimed at prospective development San Blas municipal district of Madrid.
\end{abstract}

\section{Introduction}

\subsection{General provisions}

Development of energy saving and improvement of energy efficiency in construction and public utilities sector is one of the priorities in each country. It is known that the buildings account for $40 \%$ of energy consumption volume in the European Union (The European Parliament ... Directive 2010/31/EU). The old housing facilities stock possesses considerable heat losses and is overheated through enclosures, thus leading to extremely overcharged utility bills connected with maintenance of comfortable living conditions in the apartments. Therefore, the most important measures in the European construction sector are reduction of energy consumption, use of renewable energy sources necessary for decrease of energy dependence in the European countries, and reduction of greenhouse gas emission

\footnotetext{
*Corresponding author: evn.elistratov@gmail.com
} 
(The European Parliament ... Directive 2010/31/EU). Failure to use environmentallyfriendly natural materials in interiors finishing and use of outdated air-cleaning technologies when airing the living rooms have adverse impact on microclimate of residential facilities (Derbez, M., ... 2018, Wells, E. M., ... 2015). Combination of such direct factors eventually leads to deterioration in the quality of life in general.

For the purposes of modernization of housing facilities stock, energy saving and rational use of natural resources, the authorities of Madrid have launched the urban program called Mad-Re "Madrid Recupera" (Plan Mad-Re, 2016). This program, which gradually covers the entire capital, is designed for a long-term perspective and aimed not only at improvement of living conditions of the citizens, but at increase of social cohesion of district community.

The article describes the project for renovation of the developed area in microdistrict Colonia Ciudad Pegaso (http://www.madrid.es/... .pdf), located in the western part of Rejas neighborhood and belonging to San Blas municipal district of Madrid. Following the sustainable development concept, the authors have built the project strategy - renovation of the apartment block of Madrid, included to Mad-Re program.

Design specification and initial design data for the area were received by the authors in 2017 from the official website of Isover Saint-Gobain http://www.isover-students.ru (International Edition of ... Isover, 2017) within the framework of 13th International Competition "Design of Multi-Comfort House - 2017" developed and organized by the company Isover Saint-Gobain in cooperation with the Department of Architecture of Madrid and Department of Sustainable Urban Development of Madrid Municipality.

In accordance with the design specification the project provides solutions for the following tasks:

1) renovation of residential buildings taking into account the requirements of Isover multi-comfort house, including the possibility to use the alternative sources of energy;

2) modernization of architecture of residential low-rise bedroom districts of Madrid;

3) putting into operation of new housing spaces;

4) reorganization of storage places;

5) design of non-residential facilities for public and commercial purposes;

6) creation of barrier-free environment for comfortable living of different social groups, including people with limited mobility;

7) zoning of the area for private and public zones;

8) proposal of the modern scenario for use of the urban space and increase of economic attractiveness of the living space.

\subsection{Brief overview of design territory}

The determining factor for structural and spacing solution of the microdistrict territory was standard development of 1950-1960-s intended for provision of housing to employees of Pegaso Tractor Plant. The majority of residential houses have the same building dimensions, structural scheme and construction system.

The project area is located in the block limited by the avenues Quinta and Segunda and streets Nueve and Diez (Figure 1). The renovation project covers two buildings built in 1956 (Building \# 1 and Building \# 2), single-storeyed sheds (Territory 2, 3), court-yard (Territory 1) and a small square (Territory 4 ). 


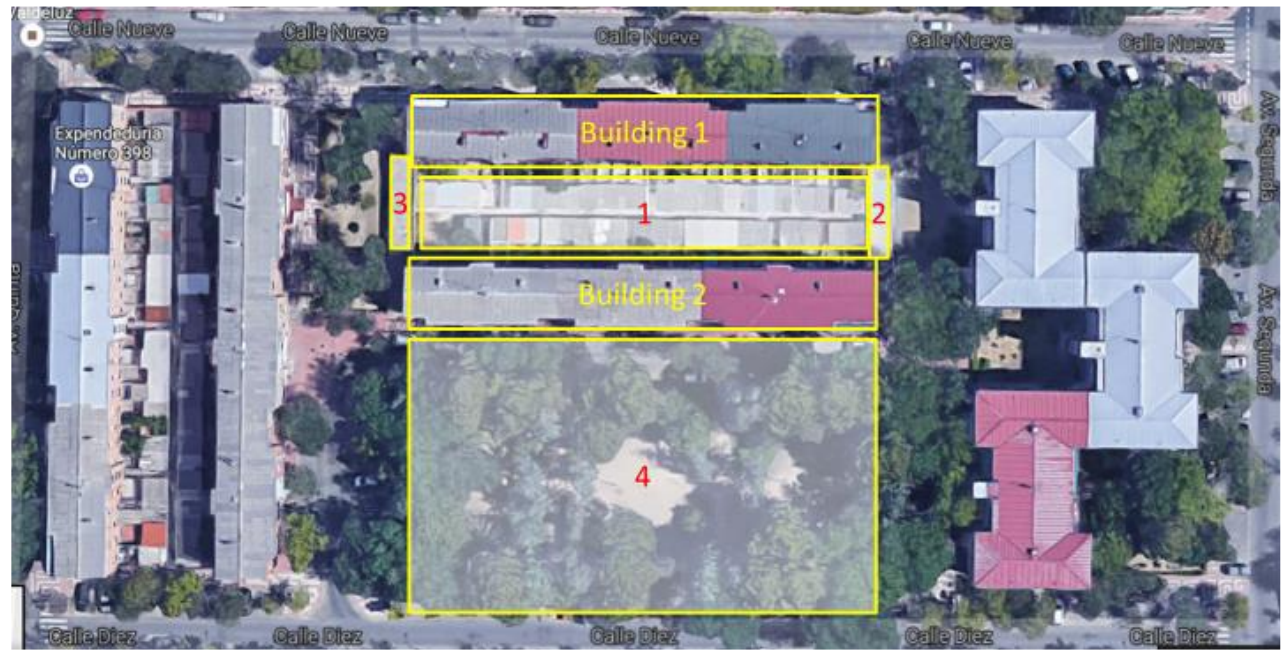

Fig. 1. General layout of renovation area. The layout includes: Building \# 1, Building \# 2; 1 - courtyard; 2, 3 - single-storeyed sheds; 4 - square. Source: Google Maps.

The Building \# 1 (Figure $2 \mathrm{a}, \mathrm{b}$ ) is a residential apartment three-section four-storeyed building in the form of a rectangle with dimensions of $69.6 \times 9.2 \mathrm{~m}$. The roof is double-pitch with a cold attic. Ridge elevation from the finished floor level of the 1 st floor is $13.2 \mathrm{~m}$. Structural layout is wall-type with longitudinal load-bearing walls made of ceramic bricks. The width of outside walls, taking into account $15 \mathrm{~mm}$ finish plaster coats, is $320 \mathrm{~mm}$. The basement floor is $1.4 \mathrm{~m}$ high and used for conduit of water supply and sewerage systems. The walls and slabs of the basement floor are reinforced concrete.

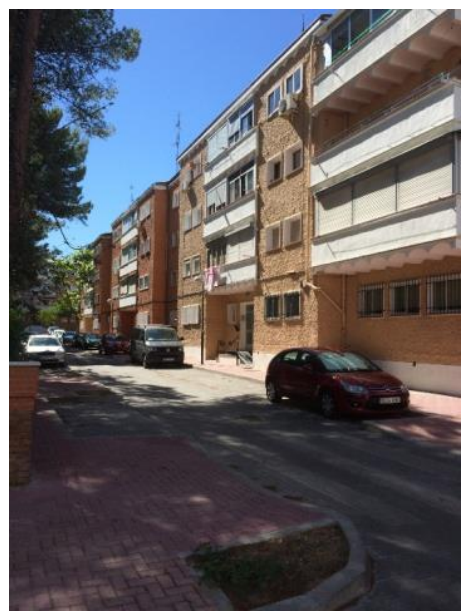

a)

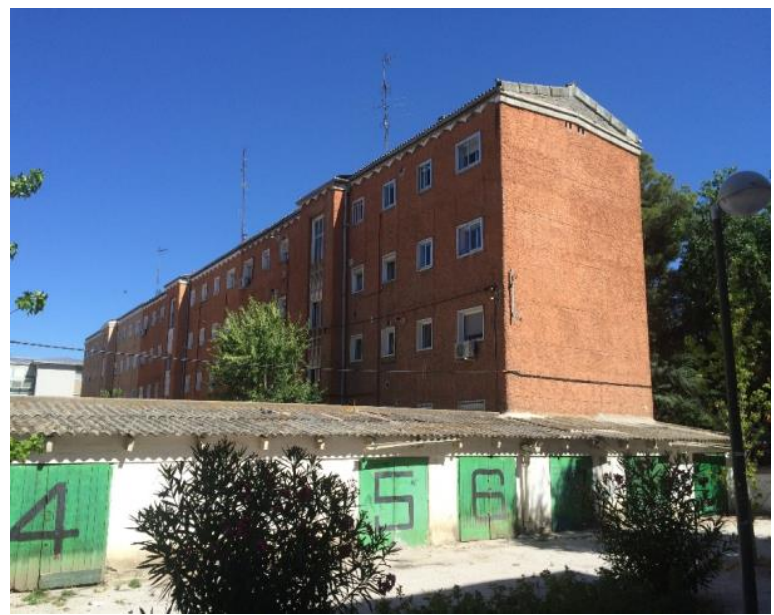

b)

Fig. 2. General layout of the Building \# 1: a - front façade as viewed from Diez Street, $\mathrm{b}$ - elevation facing yard and flank facade.

Landings are non-standard with different number of stairs. There are no entrance ramps or lifting facilities for social groups with limited mobility. Staircase extension is standard with outdoor lighting coming through window apertures of outside walls. Stair width is $0.89 \mathrm{~m}$. There is no elevator. 
The building is not connected to the municipal heating network. For the purposes of heating and hot water supply each apartment is equipped with an individual gas or electric boiler. The Building \# 1 does not meet the requirements of Isover multi-comfort house.

The Building \# 2 is completely identical to the Building \# 1 .

The court-yard from both streets is closed. It can be accessed only from staircase extensions of residential houses. Initially this space was designed as a patio. At the moment of inspection (2017) it was found that the part of the yard territory is built in two rows with single-storeyed sheds, and the other part is divided into numerous open areas separated from each other by mesh partitions (Figure 3). Many household structures need to be repaired. Open areas are abandoned.

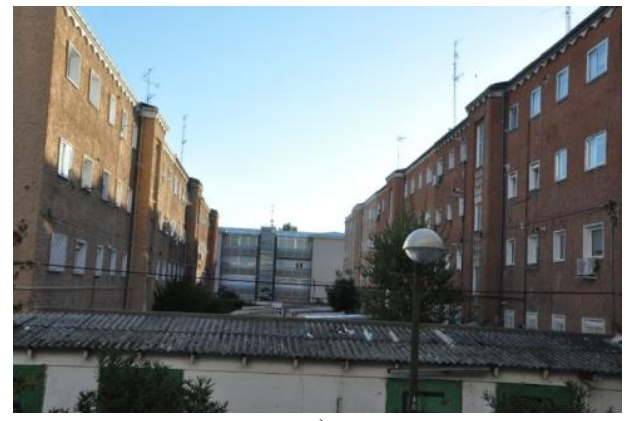

a)

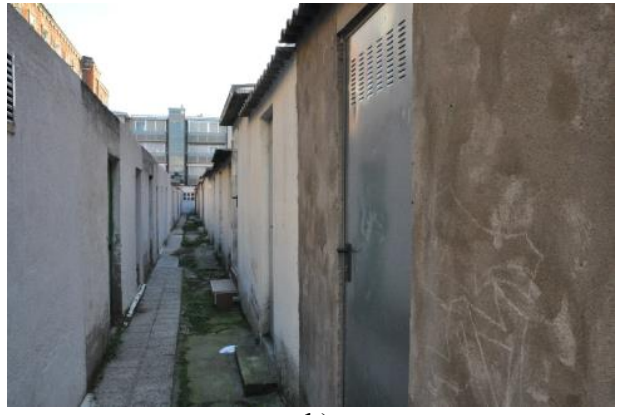

b)

Fig. 3. Court-yard (territory \# 1): $a$ - general view; $b$ - access to the shelds.

The Territories \# 2 and \# 3 are rebuilt with single-storeyed sheds, which are accessed from the street side (from outside).

The square, which occupies the territory \# 4, is located in the south of the project area and is adjacent to the residential house \# 2 on the one side, and from the other side - to Diez Street. The territory of the square is mainly planted with evergreen species of trees and bushes, does not have definite regular planning, and recreational space is not arranged taking into account the interests of different social groups. Inside the square there is an open central ground where there are several benches for rest of the citizens. The square is located above the level of the surface of adjacent streets. Elevation difference is from 0.4 to $0.9 \mathrm{~m}$. Due to absence of entrance ramps or outside lifting facilities the access to the square is inhibited for social groups with limited mobility, and for wheelchair persons it is impossible at all without outside help.

Transport vehicles are allowed to stop and park in all streets and roads of this block. On a long-term horizon there are no difficulties connected with parking the cars of residents and their guests.

The set of problems, found during inspection of the territory, indicates to importance and significance of the completed project for innovation of the area in Colonia Ciudad Pegaso microdistrict. Timeliness of the project implementation is supported by the policy of Madrid administration which is aimed at renovation of residential houses not only in the city center, but in working outskirts of the Spanish capital as well. Interest of authorities in development of energy saving and improvement of energy efficiency of the housing facilities stock served as a ground for holding the International Competition "Design of Multi-Comfort House - 2017" in 2017 in order to draw global attention to the specified problems. 


\section{Description of the project completed}

\subsection{Project concept}

In the context of historical development of San Blas district the authors offered modern scenario for use of the urban space. The project concept lies in unification of free-standing buildings and creation of the integrated modern residential complex: the existing buildings \# 1 and 2 were renovated and new sections in the territories \# 2 and 3 were designed in accordance with the criteria of "Isover Multi-Comfort House", new solutions concerning the court-yard, storage places and square were elaborated.

\subsection{Planning concepts of residential and non-residential premises}

Construction of energy efficient buildings provides not only new opportunities for business, but develops innovations in architecture and construction (Mlecnik, E., 2013). The project provides for putting into operation of $530.0 \mathrm{~m} 2$ of new residential premises which include 24 separate apartments, where 12 are single-bedroom, 6 - three-bedroom, 6 - four-bedroom apartments. Renovation of the buildings \# 1 and 2 also includes construction of mansard roof above the fourth floor. Minimum height of the premises from the floor to sloping part of the ceiling is $1.8 \mathrm{~m}$, which is determined by creation of confortable living conditions. Planning of attic rooms is similar to planning of typical floors of the building.

The Figure 4 provides the layout of typical floor of the residential complex. Fourstoreyed side sections have design dimensions $10.9 \times 17.0 \mathrm{~m}$. On each floor there are two single-bedroom apartments with the option of further replanning. Availability of combination accessible roof with well-designed observation decks will allow the residents of the complex to rest comfortably in the fresh air during siesta hours.

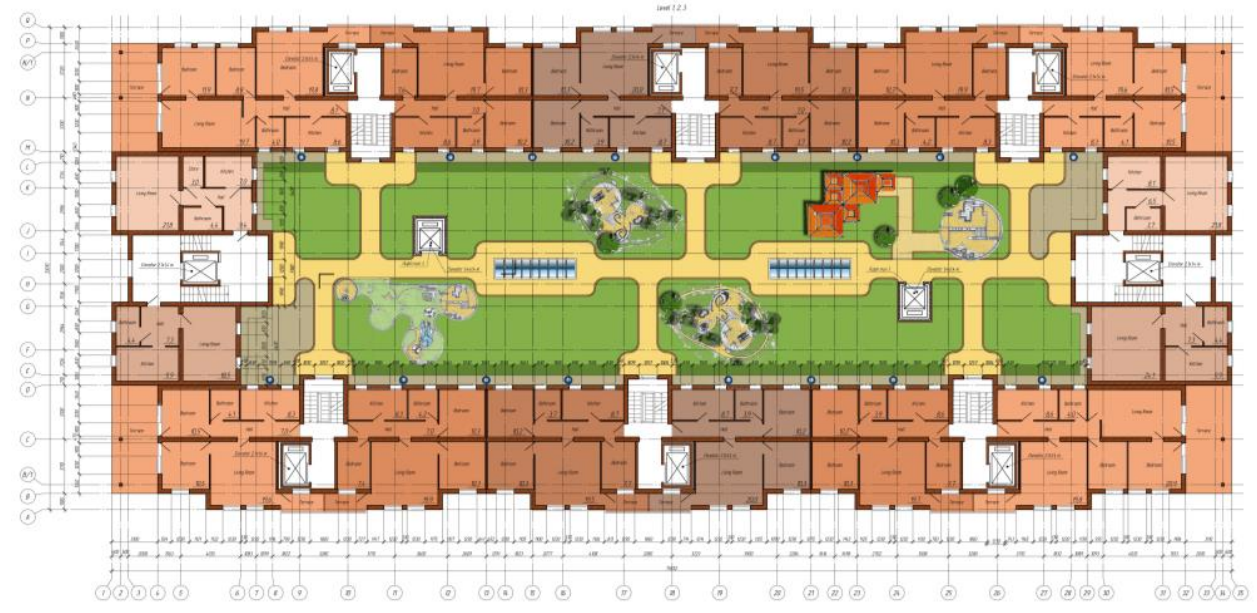

Fig. 4. Layout of the typical floor of the residential complex.

Having explored the problems of people living in the apartments on the first floors, in particular, excessive shadowing of the rooms, prying eyes of people walking outside, easy invasion to the house from outside, etc., the authors came to a conclusion about impossibility to implement certain measures aimed at improvement of comfort and safety of living in these conditions. The most reasonable measure on change of the current situation was rehousing of residents from all apartments on the first floor, registration of apartments as non-residential properties and their further use for public and commercial 
purposes. In accordance with the needs of local residents these premises include: foodstore, drug-store, animal clinic, tailor shop and shoe repairs, bakery, etc. (Figure 5). It is worth noting that non-residential premises were isolated from staircase extensions of the residential areas and equipped with separate outside entrances.

It is expected that the residents from apartments on the first floors will move either to apartments of usable roof floor, or to apartments of any floor of side sections, or move to other districts of Madrid which are covered by Mad-Re program.

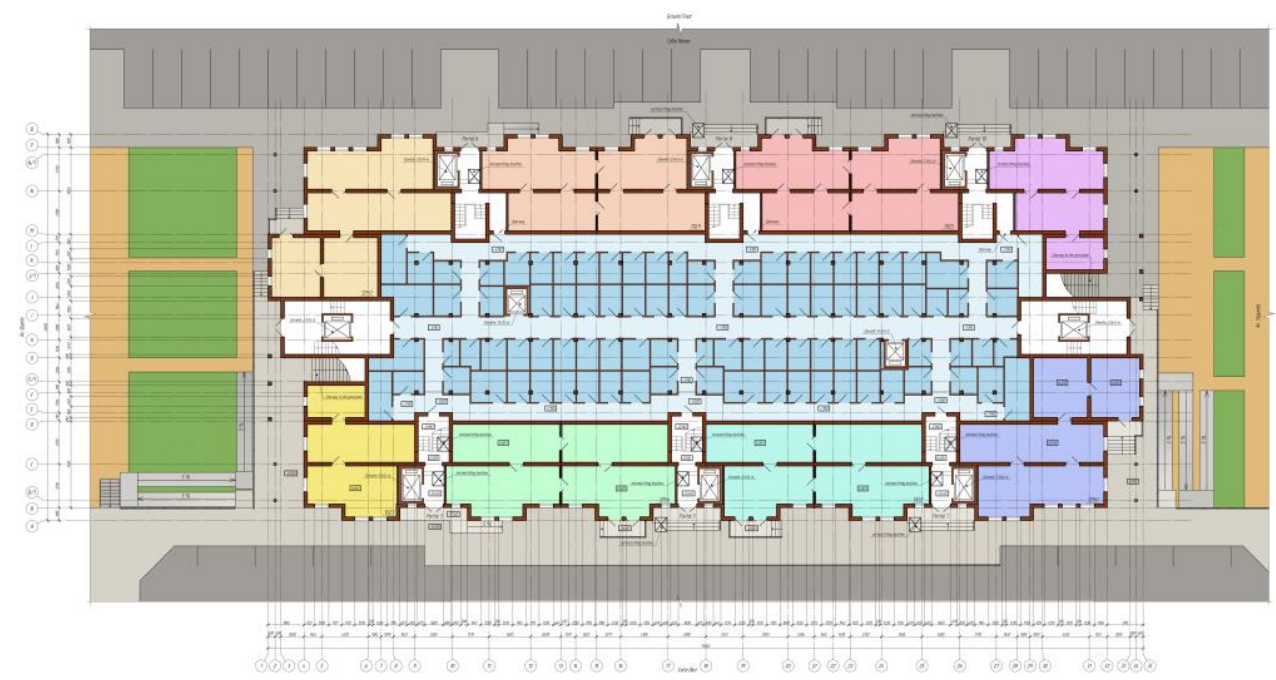

Fig. 5. Layout of the first floor with location of non-residential areas and storage places.

One of the items of design specification was preservation and modernization of storage places. Instead of out-of-date sheds, which occupied the territories \# 1, 2 and 3, the residents were offered the stockrooms located under the court-yard (see Figure 5). New storage places were equipped with convenient and spacious passages, additional outdoor lighting through roof light in the roof slab, and air ventilation system.

\subsection{Architectural solutions}

Due to elaborate architectural solutions and use of modern construction materials in cladding of façades, the residential complex advantageously stands out from the surrounding ribbon development and fits harmoniously to the environment. External image of the complex is formed by virtue of combination of natural horizontal and vertical wooden elements with Isover stucco façade system styled to masonry (Figure 6). 


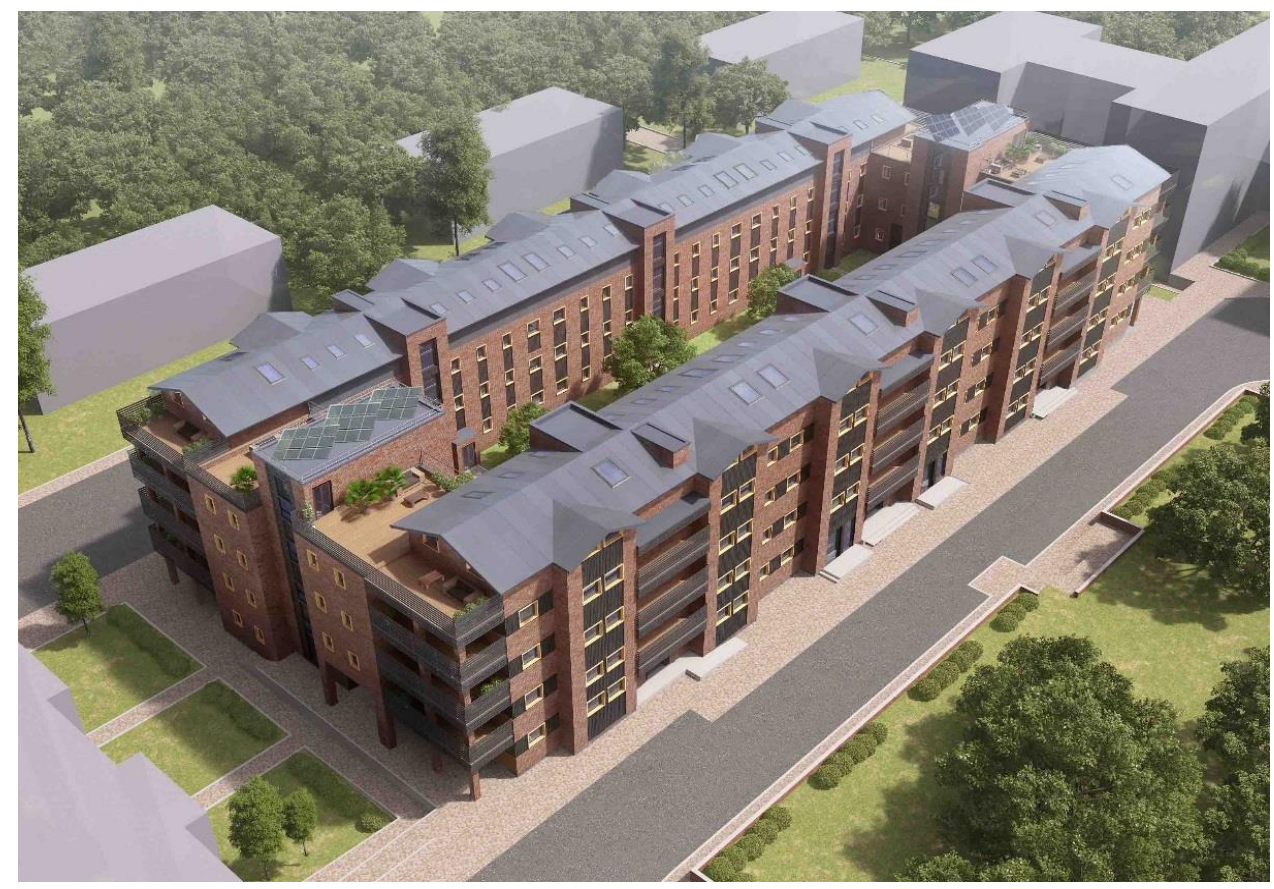

Fig. 6. General view of the residential complex.

Rhythmical alternation of vertical wood panelling with projecting volumes of avantcorps diversifies extended façade of the building. Bright architraves, framing the window apertures, were deliberately constructed deep and protruding beyond the plane of the wall. Architraves play not only a decorative role, making color accents on the brick background, but perform the function of shadowing.

Old reinforced-concrete enclosures of recessed balconies were replaced with rack wooden enclosures, which cover the end face of the floor slab and at the same time protrude over the preceding floor, thus ensuring additional shadowing. Entrance elements of the residential complex are made in the same way.

The rhythm of windows of elevation facing yards is changed by using wooden wall panels in pillars in vertical direction. These panels reproduce the idea of full wrap-around glazing of the staircase extension without transoms.

Façades of the buildings \# 1 and \# 2 are worked up by double-pitch roof with triangular frontispieces which decorate the avant-corps. The side sections are accomplished by spacious terraces with wooden enclosures.

New side sections are accomplished by accessible flat roofs with observation decks which are accessed from the staircase and elevator section. They are equipped with shadowed benches for comfortable rest and flowering plants in the planters enrich this territory performing the decorative function.

The abundance of green areas around the perimeter of the complex highlights human closeness to the nature within the city and is a necessary condition for achievement of one of the goals set by the authors - creation of comfortable living environment. 


\subsection{Thermotechnical calculation of the residential building}

Following elaboration of architectural and planning concepts of the residential complex, the project authors performed a complex calculation of the building according to the parameters of "Isover Multi-Comfort House".

"Isover Multi-Comfort House" is the concept of energy efficient building developed by Saint-Gobain. This concept not only meets the passive house criteria, but provides comfort and well-being of the citizens living in such house.

In particular, thermal comfort is achieved by the package of measures aimed at reduction of heat loss through the building envelope. Properly selected width of Isover thermal insulation material, installation of windows with low-emissivity glass, welldesigned structural assemblies without thermal bridges will guarantee maximum energy efficiency of the building. Unlike traditional developments, Isover multi-comfort houses do not produce heat releases to the atmosphere and do not disturb natural climatic conditions of populated areas. The value of specific consumption of heat energy for heating of such houses does not exceed $15 \mathrm{kWh} / \mathrm{m} 2$ per year (Catalog of Isover products ... ). As a result of energy saving, carbon dioxide emissions produced by Combined Heat Power Plants during fuel combustion are reduced.

Acoustic comfort in the premises is achieved by means of excellent acoustic isolation of the building envelope. Silence is guaranteed not only for residents of the house, but also for their neighbors during shrill parties or construction activities in the apartment. Use of SaintGobain technologies allows getting isolated from airborne noise up to $68 \mathrm{~dB}$, and impact noise up to $35 \mathrm{~dB}$.

Air permeability of Isover multi-comfort house is 3 times lower than air permeability of the standard European houses. Structural integrity is created deliberately in order to prevent uncontrolled air movement in inner casing of the building. Ventilation of the premises and supply of fresh pure air are ensured by heat recovery system for more than $80 \%$. In order to protect the building from noise and vibration produced by heat exchanger operation it is recommended to place it on the staircase extension.

Thermotechnical calculation of the building envelope by energy efficiency parameters for climatic conditions of Madrid was performed using the software MultiComfort House Designer 2.0 developed by Saint Gobain. One of the numerous advantages of the software $\mathrm{MCH}$ Designer is possibility to apply certified technical solutions, structures and assemblies from Isover legal framework (Component Suitable ... Saint-Gobain Isover), due to which thermal bridges in the envelopes are excluded and integrity of the external envelope is ensured. The calculation included the conditions on building orientation with respect to the cardinal directions, degree of active and passive shadowing, airing duration of the premises, performance coefficient of heat exchanger and other factors due to which we designed the building of A+ efficiency class with annual heat consumption of $12.2 \mathrm{kWh} / \mathrm{m} 2$ per year upon maximum permissible indoor temperature of $23^{\circ} \mathrm{C}$ in hot summer.

Such high comfort indices are achieved with the help of insulation of the building envelopes by Isover slabs. In particular, the project provides for insulation with the following materials:

a) inside walls of the basement floor - Isover Topdec DP 1032 Ultimate - $60 \mathrm{~mm}$;

b) outside walls of the basement floor - Isover Exporit EPS PDP $1-200 \mathrm{~mm}$;

c) basement ceiling from the basement floor - Isover Topdec DP 1032 Ultimate - 120 $\mathrm{mm}$;

d) external walls - Isover Kontur FSP 1-032 Easy Fix - 320 mm;

e) roof of the attic floor - Isover Integra AB SolidBlack $035-200 \mathrm{~mm}$, Isover Integra ZKF-1 032 - $140 \mathrm{~mm}$;

f) built-up roof - Isover Metac FLP 1 Duratec - $360 \mathrm{~mm}$. 
The project provides for use of alternative sources of energy. Specifically, solar panels installed on double-pitch roofs are used for heating and hot water supply. Geothermal heat pumps were not considered in the project because the possibility of their installation must be coordinated with the existing utility networks laid in the ground (underground) of the project area. Possibly the pumps may be installed in the territory of the square (Caird, S., ... 2012).

\subsection{Private and public zones of the residential complex}

After renovation the street spaces of the residential complex have clear separation into private and public zones where the people of different ages and social strata can meet and communicate thus grouping by interests. For this purpose, the concept of private yard-park and public square is implemented in the project. Therefore, both large territories are zoned into several micro-grounds where simultaneously can rest both children and adults.

The yard-park is located on the accessible roof area above the stockrooms and available only for residents of this complex (Figure 7). It consists of foot walks, green plantings and benches for have a good rest located in the shade and sand-pits for children. The project designers provide for performance of dendrological works taking into consideration various landscape design of the territory thus enabling to set trees with developed root assemblage. The required areas of stockrooms with changing of their divide walls into supporting walls are supposed to uses as a planting bunker. Natural airing of the yard is performed through two wide arches, located in frontal sections of the residential complex and provide additional entrances to the court-yard.

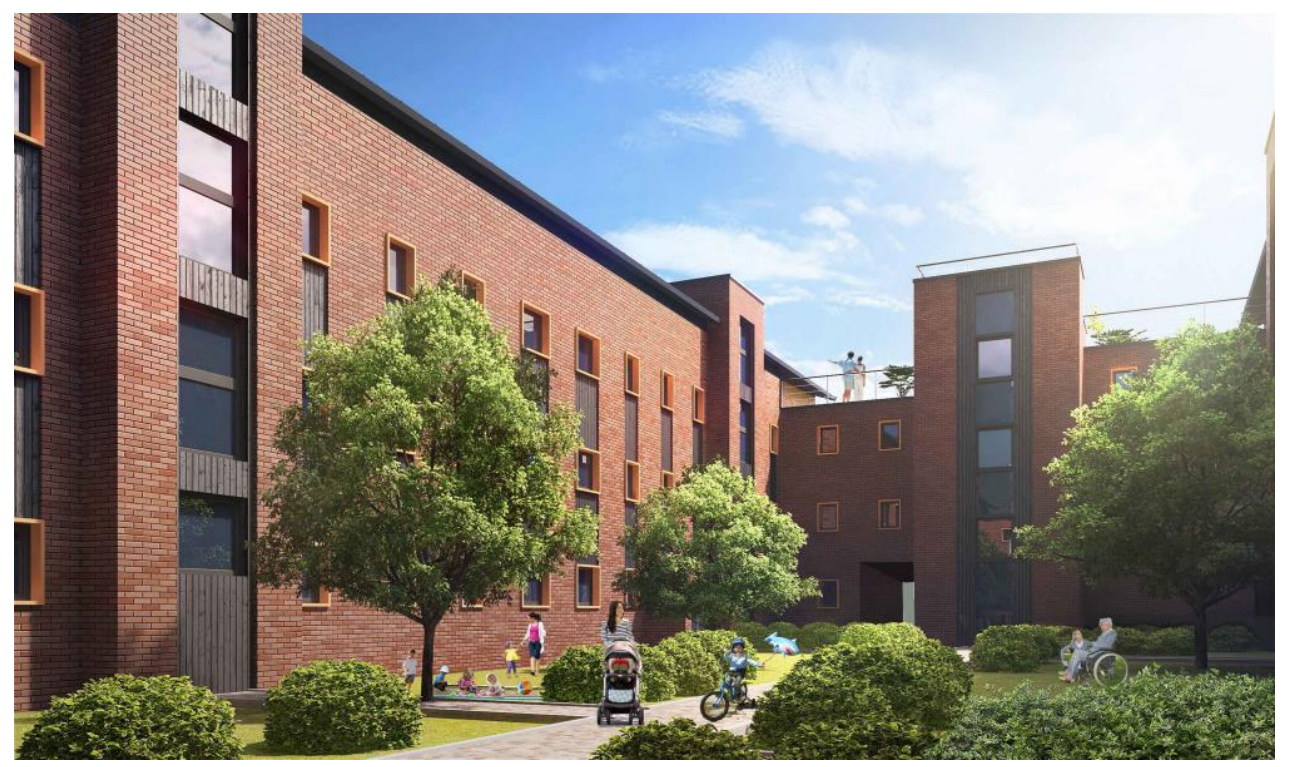

Fig. 7. Yard-park of the residence complex.

Apart from the private ground, the project provides for the public zone represented by a square and accessible for all citizens.

The project designers did not intend to change this territory significantly. The measures aimed at development and improvement of the square include equipage of the grass lawns with a sprinkling system, provision of light illumination, installation of mobile pavilions for rest of citizens during siesta, improvement of play zones for children of various ages, provision of areas for workout and installation of sports street equipment. 
Modern social rhythm requires necessity in twenty-four-hour lively cycle of the city and its components. That is why the artificial environment created by means of electricity supply is the same utilitarian necessity. Key principles of light design are performed by means of multidirectional vectors of initial source imitation (Harlamov, M. V., 2011).

In this section the main task of the project is to highlight the square artistically at night time. Except for the standard public lighting, modern architectural lighting of landscape is provided in the square. Due to this lighting one can see only the light, but not its source. Lighting fixtures and illumination are located so that the light not strikes the eye, but softly illuminate this or that detail of the square.

All these measures are aimed to make the square territory safe and attractive for various segments of population.

\subsection{Vertical planning of the area}

General availability of the complex for social groups with limited mobility is provided not only by means of vertical planning of the area with nonthreshold access to the building, entrance ramps at landing platforms and level difference places, but with location of vertical and inclined lifting facilities at those area of the residential complex where the entrance ramps cannot be provided.

All staircase extensions are equipped with modern soundless elevators produced by Spanish company Orona with cages $2.1 \times 1.4 \mathrm{~m}$. Such elevators enable the wheelchair persons turning in the cage without external assistance and transport lying patients on hand frames thus allowing comprehensive medical care of all people of the complex. The elevators with a shaft are designed instead of one room, but the lack of living area is compensated by spacious recessed balcony in these apartments. Vibration and sound insulation at the places of the shafts adjacent to the walls of apartments provide the required acoustic comfort.

The elevators with cages $1.4 \times 1.4 \mathrm{~m}$ installed inside the yard enables the wheelchair persons full use of stockrooms.

\section{Conclusions}

Due to the performed work, the project designers created new architectural appearance of residential development with application of the unified construction solutions and modern energy saving technologies.

Application of construction materials and technical solutions taken from official catalogs of Saint-Gobain Company enabled to design buildings which meet the requirements of Isover multi-comfort house. In particular, the designed residential complex belongs to A+ class of energy efficiency with annual heat consumption $12.2 \mathrm{kWh} / \mathrm{m} 2$ which meets the regulations of Article 9 of Directive 2010/31/EU. According to this Directive since January 01, 2021 all newly constructed buildings must be practically with zero energy consumption.

In order to improve living conditions in apartments and create comfort and affordable area for social strata, under Mad-Re urban program the new objects were implemented in the renovation project. In particular, the designers provide for living attic floors, new side section, elevators, lifting facilities and entrance ramps, stockrooms, observation decks at the accessible roof areas, safe private landscaped inner yard space, landscaped square, nonresidential premises for public and commercial purposes etc.

Combination of the performed activities for renovation of the area sets the pulse for improvement and development of this territory and aimed at formation of comfort urban 
environment and increase of economic attractiveness and prospective development of all micro-district Colonia Cuidad Pegaso (in San Blas district).

\section{References}

1. S. Caird, R. Roy, S. Potter, Energy Efficiency 5, 283-301 (2012)

2. Catalog of Isover products based on fiberglass. Professional safe solutions (2015)

3. Component Suitable for Passive Houses: Thermal bridge free connection detail (SaintGobain Isover)

4. M. Derbez, G. Wyart, E. Le Ponner, O. Ramalho, J. Ribéron, C. Mandin, Indoor air quality in energy-efficient dwellings: Levels and sources of pollutants Indoor Air 28(2), 318-338 (2018)

5. M.V. Harlamov, Creation methods of architecture light image 3(28), 28-33 (2011)

6. http://www.madrid.es/UnidadesDescentralizadas/UDCEstadistica/Nuevaweb/Territorio ,\%20Clima $\% 20 y \% 20$ Medio\%20Ambiente/Territorio/Cartograf $\% \mathrm{C3} \% \mathrm{ADa} / \mathrm{Mapas} \% 20$ de\%20dist $\% 20$ y\%20bar/20\%20San\%20Blas.pdf

7. International Edition of Multi-Comfort House Students Contest Edition 2017 by Isover, http://www.isover-students.ru

8. E. Mlecnik, Journal of Cleaner Production 10, 103-111 (2013)

9. Plan Mad-Re, http://www.madrid.es/portales/munimadrid/es/Inicio/Vivienda-yurbanismo/Plan-MAD-E?vgnextfmt=default\&vgnextoid=e000cb5ee0993510VgnVCM $1000001 \mathrm{~d} 4 \mathrm{a} 900 \mathrm{aRCRD} \&$ vgnextchannel $=593 \mathrm{e} 31 \mathrm{~d} 3 \mathrm{~b} 28 \mathrm{fe} 410 \mathrm{VgnVCM} 1000000 \mathrm{~b} 205 \mathrm{a} 0$ aRCRD

10. Plan Mad-Re, https://planmadre.madrid.es

11. Official Journal of the European Union 18.06, 13-35 (2010)

12. E.M. Wells, M. Berges, M. Metcalf, A. Kinsella, K. Foremen, D.G. Dearborn, S. Greenberg, Building and Environment 93(2), 331-338 (2015) https://www.sciencedirect.com/science/article/pii/S0360132315300354 